\title{
The Core of the Apple: \\ Dark Value and Degrees of Monopoly in Global Commodity Chains
}

\author{
Donald A. Clelland ${ }^{1}$ \\ University of Tennessee (Emeritus) \\ Donclelland@aol.com
}

\begin{abstract}
The capitalist world-economy takes the form of an iceberg. The most studied part which appears above the surface is supported by a huge underlying structure that is out of sight. Unlike the iceberg, the world-economy is a dynamic system based on flows of value from the underside toward the top. These include drains of surplus (expropriated value) that take two forms: visible monetarized flows of bright value and hidden un(der)costed flows that carry dark value (the unrecorded value of cheap labor, labor reproduction and ecological externalities). Commodity chains are central mechanisms for these surplus drains in the world-economy. At each node of the chain, participants attempt to maximize their capture of bright value through wages, rent and profit. They do this by constructing differential degrees of monopoly (control of the markup between cost and sale price) and degrees of monopsony (control of markdowns of production costs). However, this process depends upon the transformation of dark value into bright value for capture. Via an examination of the Apple iPad commodity chain, I show how the bright value captured by Apple depends on the dark value extracted by its suppliers. Dark value is estimated by measurements of the value of under-payments for wage labor, reproductive labor and environmental damage in Asian countries, especially China. Surprisingly, most dark value embedded in the iPad is captured by final buyers (mostly in the core) as consumer surplus.
\end{abstract}

Keywords: Apple, Chinese labor, consumer surplus, dark value, monopsony, unequal exchange, value capture

We should think of the modern world-system as an iceberg economy in which uncosted labor and resources comprise the thicker submerged ice layers that are blocked from view beneath a thin top stratum that is counted as the visible official economy (Mies, BennholdtThomsen and Werlhof 1988). From this vantage point, we realize that the total world surplus is far greater than the cumulative GDPs. We also realize that commodity chains are far more than networks in which "value is added" at nodes. ${ }^{2}$ From a world-system perspective, these networks are exploitative structural relationships in which a vast array of unequal exchanges occurs among nodes of the chain and across zones of the world-economy (Wallerstein 1983). Indeed,

\footnotetext{
1 I would like to thank Wilma Dunaway and three reviewers for their suggestions about ways in which I could tighten and strengthen this essay. I would also like to thank Jennifer Bair for her encouragement and support.

${ }^{2}$ I use the world-system conceptualization of commodity chain, although the careful reader will recognize the influence of later variants. See Bair (2009) for an explanation of differences among these approaches.
}

Copyright ${ }^{2014}$, American Sociological Association, Volume 20, Number 1, Pages 82-111, ISSN 1076-156X 


\section{Journal of World-Systems Research}

capitalism is grounded in surplus extraction chains through which powerful firms exercise degrees of monopoly to capture massive transfers of what I term bright value and dark value. ${ }^{3}$ Using world-systems analysis, this study examines one of those chains. After a brief methodological discussion, I explicate my conceptual framework of bright and dark value extraction and of degrees of monopoly in commodity chains. In the fourth part, I examine the differential expropriation of bright value through degrees of monopoly in the iPad commodity chain. In the fifth part, I offer an empirical investigation of the expropriation of dark value in the iPad chain through (a) extraction of hidden labor surpluses, (b) appropriation of unpaid inputs from laborer households and communities, and (c) surplus extraction through ecological externalities.

\section{Methods of Inquiry}

Between mid-2010 and mid-2011, Apple sold a little more than 100 million iPads, all assembled in China. This study explores the commodity chain for that product. In 2011, Apple integrated 748 suppliers of materials into its production network ( 82 percent of them based in Asia, 351 of them in China) (Apple 2012). Despite this array of input sources, final assembly is centralized at seventeen plants. This form of commodity chain is governed by a lead firm that sets strict design and production standards for each component of its finished item (Gereffi, Humphrey and Sturgeon 2005). As shown in Figure 1, there were at least six tiers of first generation iPad suppliers: (a) one assembly firm, (b) twenty manufacturers and sub-assemblers of major components, (c) producers of subcomponents used to manufacture components, (d) subcontractors to those material producers, (e) firms that extracted and processed raw materials, and (f) ancillary inputs into production and management processes. Due to lack of corporate transparency, however, I can analyze closely only the first three tiers. Headquartered in the United States, the European Union, South Korea, Taiwan, Japan, and Singapore, lead suppliers outsourced most of the manufacturing to China. ${ }^{4} \mathrm{I}$ emphasize this aspect of the supply chain because previous research underestimated the degree to which the iPad and its components were manufactured in China. ${ }^{5}$ In concentrating iPad assembly and component manufacturing in China, Apple and its suppliers have followed the global trend. ${ }^{6}$

\footnotetext{
${ }^{3}$ My concept of dark value is an extension of Emmanuel's (1972) theory of unequal exchange, but I challenge his assumption of international equal rates of profit (cf. Amin 1976, 2010). It is a basic argument of the original worldsystems conceptualization (Wallerstein 1983, Hopkins and Wallerstein 1986) that commodity chains are surplus extraction chains based on unequal exchange.

${ }^{4}$ Contact the author for a list of first generation iPad suppliers.

${ }^{5}$ Kraemer, Linden, and Dedrick (2011) assigned estimates to firm headquarter countries or to an "unidentified" category, failing to document the extent to which production sites were located in China or other Asian countries.

${ }^{6}$ There are more than 15 million workers in the global electronics industry, with China as the production hub (Sustainable Trade Initiative 2011).
} 


\section{Figure 1. Supply Chain for First Generation Apple iPad, April 2010- March 2011}

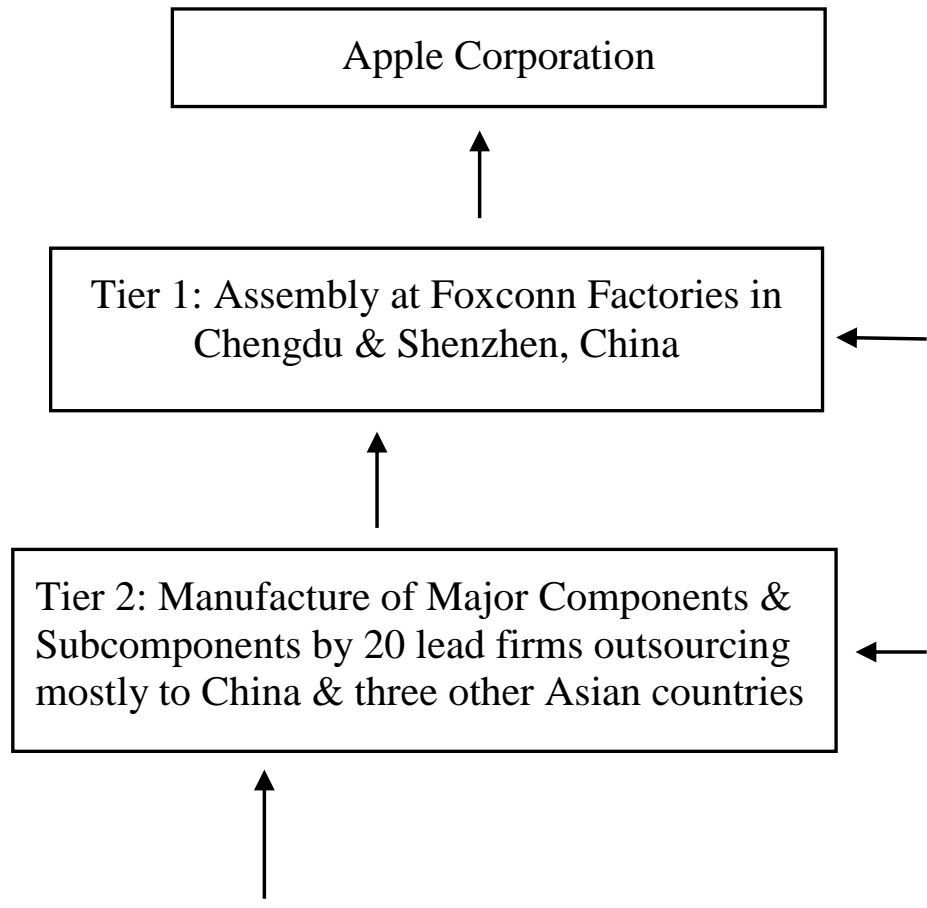

Tier 3: Production of Subcomponents Used to Manufacture iPad Major Components in China and Philippines

1. Production of seminconductor chips from silicon

2. Production of parts from lathanum and rare earths

3. Production of parts from tantalum, aluminum, iron, copper, gold and tin

4. Production of plastic parts

5. Production of aluminum silicate glass

6. Production of chemicals and epoxy

7. Production of cardboard and styrofoam (shipping containers)
Tier 6: Ancillary Inputs into the Production \& Management Processes

1. Design of integrated circuits \& Manufacture of production machinery

2. Labor recruitment agencies

3. Other ancillary inputs into the production \& management processes (e.g., security, electricity, water, construction and maintenance of factory)

4. Production of goods \& services consumed by workers: (a) protective gear; (b) foods from subcontracted vendors, rural peasant households \& processing factories and (b) other formal \& informal sector goods \& services

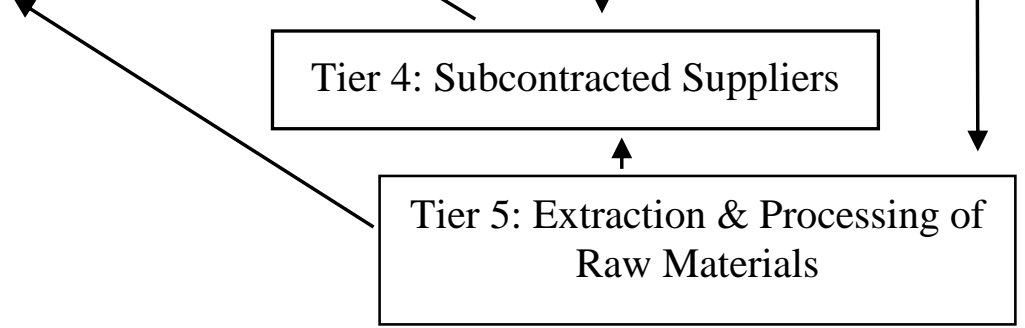

Sources: Analysis of Apple (2012), iPad teardowns, numerous NGO and company websites, newspaper accounts.

I utilized iPad product teardowns, Apple's supplier list for 2011 and extensive searching of corporate websites to identify suppliers and to determine estimates of worker compensation 


\section{Journal of World-Systems Research}

levels. ${ }^{7}$ The ground-breaking Apple iProduct research of Kraemer, Linden, and Dedrick (2011) and Linden, Dedrick and Kraemer (2011) was useful in my operationalization of measurements of key global commodity chain concepts, as well as estimates of direct waged labor costs. In addition, their research suggested to me the possibility of an extension to surplus drain analyses. While I utilized their estimates as starting points, I moved beyond their research in four key ways. Since I had the advantage of several forms of information that were not available to these earlier researchers (e.g., Apple 2012), I was able to document that lead suppliers of the first generation iPad outsourced most of their production to China. Second, I extended their estimates of waged labor costs to encompass salaried professional/managerial staff that they did not analyze. Third, I expanded their work to include the third tier of the commodity chain (see Figure 1) that they ignored. Fourth, I radicalized the analysis by exploring world-systems questions and by introducing my own conceptualizations. While I provide some methodological explanations in the narrative, I have situated many details about quantitative sources and approaches in the notes for each table.

\section{Conceptual Model}

Physicists now estimate that imperceptible dark matter and dark energy account for 96 percent of the universe and that dark energy determines the degree to which expansion can occur (Panek 2011). By analogy, I argue that invisible human and natural energy flows are converted into the dark value that forms part of the basic structure of the world-system. Like other surplus transfers that are embedded in all commodity chains, this dark energy flows from some locations and accumulates in others. It is such relationships that allow us to identify some places, organizations and groups as core, others as periphery (Wallerstein 1983, 1987). Arrighi and Drangel (1986: 1112) contend that: "Core activities are those that conquer a large share of the total surplus produced within a commodity chain, and peripheral activities are those that command little or no such surplus." In the following two conceptual sections, I will offer my central theoretical arguments about how commodity chains operate (a) to extract bright and dark value and (b) to structure degrees of monopoly.

\section{Bright and Dark Value Extraction in Commodity Chains}

In addition to analyzing the inequitable core-periphery relationship, commodity chain analyses should integrate Braudel's lowest layer of the world-economy, "material life," upon which capitalism depends (Arrighi 1994: 10-11, 25-27). However, analysts typically ignore this material life which includes the unpaid reproduction of labor within households (Dunaway 2014: 1-15). ${ }^{8}$ For that reason, I move away from the industry/firm-centric analysis of value-added (e.g.,

\footnotetext{
${ }^{7}$ Specialized companies (e.g., iSuppli and iFixit) develop teardowns for electronic products in which they identify components, their costs, and some of their manufacturers. In 2010 and 2011, Apple iProducts were the center of much of that interest.

${ }^{8}$ As Brewer (2011: 213-14) indicates, "the commodity chain concept within world-systems analysis was created, first and foremost, as a means of explaining the polarized distribution of wealth within the modern capitalist worldsystem" (also cf. Parnreiter 2012). Nevertheless, actual analysis of distribution of surplus, value-added or value
} 
Gereffi, Humphrey and Sturgeon 2005) to focus sharply on the forms of hidden value that capitalists expropriate from laborers and from the costs they externalize to households, communities and ecosystems. In other words, I invert the question of how value is added to a commodity by pinpointing the concealed value generated by workers and by several types of externalities. I will argue that these dark inputs account for as much or more value than any firm contributes to a commodity chain. Dark value is integrated into every economic transaction or commodity, making it the silenced partner that renders every bright value drain more profitable. Unlike visible bright value that is directly accumulated by the capitalist (Clelland 2012: 199200), this second type of surplus drain is externalized from economic accounting. Dark value subsidizes capitalists, but it also benefits consumers, mostly in the core, thus legitimizing the structure of the system.

At each node in a commodity chain, we begin with supply of materials, to which is added costs of direct production, management, overhead costs, and profit. The total monetarized value of these factors equals the sales price. The total value of the three factors beyond the material inputs is termed value-added at that link in the chain. The portion of this added value that is not paid out in costs is value capture (i.e., profit). All of these components, combined with sales price, become a portion of material costs at the next node in the chain, at which point the construction of new value is repeated. Since all this cumulation of value is monetarized (and measured with transparent accounting techniques), I refer to this set of ideas as the description of the bright value in a commodity chain (Clelland 2012). ${ }^{9}$

At each node of a commodity chain and within each of its constitutive elements, there are hidden inputs in the form of externalized costs that often contribute greater value than the visible elements. Wallerstein (2009: 7) points out that "the basic effort of capitalists is to externalize costs, that is, to not pay the full bill for the inputs they use." Such externalized costs are found at every node and every link of every commodity chain. Even though these factors are "uncosted" by the capitalist, they can be made visible in the money form. When a capitalist lowers wages to challenge competitors, the value of the reduction in labor costs becomes a form of dark value. If all the other costs of competitive firms are equal, the reduced labor cost has been captured as profit. In other words, dark value has been transformed into bright value. Should the capitalist cut the price to outmaneuver competitors, (s)he passes on the dark value to buyer(s) in the next node of the chain. The value of the labor input to the buyer is embedded in the product (e.g., a component part for the iPad) as dark value that can be captured by the buyer. However, the decreased wages are externalized to laborers as the need to undertake additional work hours to replace lost income that may be critical for household survival. ${ }^{10}$ This argument of dark value capture can also be applied to necessary costs of production for which the capitalist pays nothing (e.g., environmental damage).

The goal of the capitalist is to capture dark value from as many sources as possible and to transfer it into bright value. ${ }^{11}$ In a purely competitive system, all captures of dark value would quickly be matched by competitors, but this does not happen in real capitalism (Braudel 1981,

captured has been rarer among world-systems analysts (cf. Talbot 2004 as an unusual case) than among business scholars (e.g., Kaplinsky and Morris 2001).

${ }^{9}$ The model presented in this and the following section is an ideal type from which I would expect variations.

10 Since the unpaid costs are externalized to households, Mies, Bennholdt-Thomsen and Werlhof (1988) and Dunaway (2012) conceptualize this process as housewifization.

11 This is an expansion of Marx's (1993, vol. 1) analysis of the capture of surplus value from labor power. 


\section{Journal of World-Systems Research}

vol. 2: 228, 413-22). Consequently, those capitalists who capture significant levels of dark value utilize it in three ways. First, they can apply the hidden value to roll-back prices in order to attract a greater volume of consumers than their competitors. Second, the capitalist might transfer some portion of the dark value into bright value in order to expand accumulation through reinvestment. Third, the capitalist can employ the dark value to attain protection from competitors through degrees of monopoly. In order to understand the appropriation and capture of dark value, we must examine the role of degrees of monopoly within commodity chains.

\section{Degrees of Monopoly in Commodity Chains}

By degree of monopoly (Kalecki 1954), I mean the control of any mechanisms that can expand a participant's share of a surplus in variance from a fully competitive market. Most discussions of monopoly point to (a) collusion among potential competitors in setting high prices in order to collect high profits and/or (b) state protection as a source of monopoly. In contrast, I emphasize that degree of monopoly is more commonly based on advantage of scale, productivity, barriers to entry, product innovation and/or design, intellectual property rights, advertising and marketingi.e., the real-life actions that capitalists take to secure an advantage. These processes are mechanisms for establishing control over mark-ups in sales prices (Kalecki 1954). While they are sought by all participants in commodity chains, actual capture is related to the capitalist's hierarchical position in the chain. This structure is based in the reality that degree of monopoly (control of price markets) is highly dependent upon degree of monopsony, the ability to control "mark-downs" in the costs of inputs. At each node, every firm attempts to attain power over markups by constraining its supply costs. Within any node, full capture of the surplus is constrained by the relative monopsony power of the buyer (Robinson 1993). In order to cut costs deeper than the competition, each firm tends to externalize the least profitable elements of production and circulation to suppliers and distributors who face more intense competition. The firm to which production is outsourced "sells semi-dear," by passing on part of its potential surplus in the form of a reduced price, allowing the capitalist with a high degree of monopoly to "buy cheap." Obviously, this relationship is not between equals (as in the abstract model of neoclassical economics). Rather, the relationship is one of surplus extraction through unequal exchange, for capitalists construct their degrees of monopoly through unequal exchanges with producers and sellers who hold less market power. ${ }^{12}$ I am convinced that commodity chains have always tended to be organized in this manner, but today, even more so. Lead firms increasingly organize and govern commodity chains as degree of monopsony chains and mark-down chains in order to maximize their capture of value. ${ }^{13}$

\footnotetext{
${ }^{12}$ I expand upon Wallerstein's (1983: 31-34; 2004: 17-18, 26-30) notion of unequal exchange.

${ }^{13}$ I am convinced that the "global value chain" approach is mistaken in its emphasis on value-added. The whole point of the chain is value capture in the narrow sense of distribution of the surplus.
} 
Table 1. Flow of Bright Value in the iPad Commodity Chain, 2010-2011

\begin{tabular}{lcc}
\hline Activity & A & B \\
& Cost in US\$ & \% Factory Price \\
\hline Retail Price & 499 & 181.5 \\
Wholesale Price & 425 & 154.5 \\
Factory Price & 275 & \\
Gross Profit Margin (GPM) (Total "value capture") & 223 & \\
Apple Gross Profit Margin (Design, Marketing, Chain & & 54.5 \\
$\quad$ Governance, Operating Profit) & 150 & 32.0 \\
Manufacturing GPM (Tiers 1 and 2)* & 88 & 9.8 \\
Taiwan & 27 & 9.5 \\
Korea & 26 & 8.4 \\
United States & 23 & 1.8 \\
European Union & 5 & 1.4 \\
Japan & 4 & 1.1 \\
China & 3 & \\
Direct Labor to assemble iPads \& to manufacture its & & 12.0 \\
major component parts (Tiers 1 and 2) $* *$ & 33 & 9.1 \\
China & 25 & 1.5 \\
Korea & 4 & 0.7 \\
Taiwan & 2 & 0.7 \\
Philippines & 2 & 56.0 \\
Material Inputs for Major Components & 154 & \\
\hline Sous
\end{tabular}

Sources and Notes: The model of the iPad examined is the 16GB Non-3G version (2010), the simplest, least expensive model. The starting point for the figures provided is a "teardown" by iSuppli Corporation (Rassweiler 2010) that identifies the major components, most suppliers, and the estimated costs. It is likely that these estimates are somewhat high, failing to take into account Apple's strong bargaining position (degree of monopoly) (EPT Newsletter 2010). Additional suppliers and component costs have been identified from teardowns, Wikipedia (2013) and internet searches. The gross margin of each supplier is available in annual reports and is reported by stock trader internet sites. The country shares of gross margin are the cumulative shares of the suppliers with headquarters located in that country. The country shares of direct labor are the cumulative shares allocated to actual production sites. Data in column A are derived from Kraemer, Linden and Dedrick (2010: Table 1) with adjustments for my revised list of iPad suppliers. Data in column B are calculated by dividing data in column A by the factory price $(\$ 275)$.

* Includes Singapore (less than 1\%) represented in the rounded total. ** Includes Singapore (less than 1\%). Numbers have been rounded.

This approach to commodity chains as gradational, hierarchical degrees of monopsony is in accord with a monopoly capitalism approach to world-systems analysis. Braudel directly assaulted "the conflation by classical economists (including Marx) of the market and capitalism" (Wallerstein 2004: 18). Indeed, Braudel (1981, vol. 2: 228, 413-22, vol. 3: 620) drew a sharp distinction between the competitive market facing most firms and the "anti-market" sphere of "real capitalism," the realm of the monopolists who have shaped and dominated the capitalist world-system. ${ }^{14}$ As Wallerstein (2004: 26) observes, capitalists "always prefer a monopoly, for then they can create a relatively wide margin between the costs of production and the sale price," thereby securing profit shares well above the market average. The capitalist world-economy is a degree of monopoly system because capitalists seek to avoid market competition through "competitive advantage." Building upon Braudel and Wallerstein (1983: 17, 29, 33-34, 55), I contend that the struggle for degrees of monopoly is an historical driving force of capitalism but

${ }^{14}$ Talbot (2011) examines the relationship of Braudel's three layers within the historic coffee commodity chain. 
that, of necessity, few firms capture high degrees of monopoly. The system is sharply gradational, following a steep curve of degrees of monopoly. As a result, most capitalists in the market sphere are subjected to exploitation by the minority of capitalists in the anti-market sphere who hold strong degrees of monopoly.

\section{Empirical Analysis of Apple Degrees of Monopoly}

It is common knowledge that Apple products have generated massive profits, but how is value added and captured within its commodity chains? Table 1 draws attention to the bright value in the iPad commodity chain and allows us to see how visible surplus is distributed. Note that 45 percent of the retail price is added after production, i.e., the $\$ 224$ difference between factory price and retail price. Apple collects two-thirds of this difference. Most directly, this large number reflects Apple's buying power, its ability to drive down the input costs shown in Table 1 (Column A, below Apple's Gross Profit Margin, GPM). Moreover, Apple obtains greater profits from the proportion of sales through its own stores (see later discussion). The payoffs exhibit some rather stunning inequalities. First, the manufacturing GPM (\$88) of the total value captured by all of the Tier 1 and Tier 2 firms that produced the iPad barely exceeds one-half of the GPM of the non-producer Apple. Firms headquartered in Taiwan, Korea and the United States corner 8 to 10 percent each of the factory price. Second, the direct labor cost (\$33) is astonishingly low, less than 40 percent of the firms' gross profit share. The disparity is based partially on the outsourcing of production to cheap labor in China. While China accounts for three-quarters of all direct labor costs, only 2 percent of the total gross profit margin (\$223) stays in that country. Only 12 percent of the factory price is retained by waged workers, so Apple captures 4.5 times more of the surplus than its offshored iPad working class.

Empirical Measures of Degrees of Monopoly in the iPad Chain. One crude measure of degree of monopoly is the gross profit margin (GPM), i.e., the proportion of corporate sales revenue that remains after payment of costs of materials and waged labor involved in production (see Tables 1 and 2). ${ }^{15}$ Apple is an advanced example of a "fabless" company, a corporation that designs, patents and sells complex innovative integrated circuit systems, the manufacture of which it outsources (i.e., fabless $=$ fabricationless). Plant, equipment and production labor costs are turned over to independent subcontractors (Kumar 2008). Four of Apple's Tier 2 core suppliers are fabless companies that outsource to Taiwan or China. Of necessity, such firms have high gross margins, as salaried research and development costs are large compared with the costs of labor and material inputs. Apple's 35 percent gross profit margin is not highly unusual among industries characterized by rapid innovation and maintenance of patent rights (see Table 2). The

\footnotetext{
${ }^{15}$ GPM is sometimes termed "value capture" in global commodity chain analyses. GPM (often called gross margin) is not what the rhetoric makes it seem. It encompasses research and development (including operating systems and software), capital investment, and the salaries of engineers, supervisors, managerial and administrative personnel at production sites, as well as headquarters managerial and sales personnel. Firms like Apple and a few of its suppliers that focus on innovation and design have high gross margins because of the high salaries of technical employees. Firms whose production regimes are based on expensive high-tech plants and equipment must also have high gross margins.
} 
high GPMs enjoyed by most of Apple's core suppliers are based on their provision of innovative, patented components for which Apple is unable to drive prices down. Still, their unique high-cost components garner only a $\$ 59$ share, roughly 20 percent of the production costs. Most of the value added by component prices is generated by firms located in the Asian semiperiphery other than China ( $\$ 199$ for manufacture and assembly). These suppliers score 80 percent of the GPM of only $\$ 53$ (i.e., 60 percent of the \$88 GPM captured by Tier 1 and 2 suppliers). The lower mean GPM of these firms represents their relatively weak bargaining positions in setting component prices. In these cases, Apple can locate alternative sellers. Consequently, the average GPM of Tier 2 Asian suppliers is 21 percent, reflecting their lower degrees of monopoly in relation to Apple and a few of its core suppliers (see Table 2).

Table 2. Corporate Degree of Monopoly as Represented by Gross Profit Margins and Operating Profit Margins of Apple and Its iPad Suppliers, 2010-2011

\begin{tabular}{|c|c|c|c|c|c|}
\hline Corporations & $\begin{array}{c}\text { A } \\
\text { \$US Share of } \\
\text { Wholesale } \\
\text { Price }\end{array}$ & $\begin{array}{c}\text { B } \\
\text { Corporate \% } \\
\text { Gross Profit } \\
\text { Margin (GPM) }\end{array}$ & $\begin{array}{c}\text { C } \\
\text { GPM Share of } \\
\text { iPad Unit } \\
\text { Price \$US }\end{array}$ & $\begin{array}{c}\text { D } \\
\text { Corporate \% } \\
\text { Operating Profit } \\
\text { Margin (OPM) }\end{array}$ & $\begin{array}{c}\text { E } \\
\text { OPM Share of } \\
\text { iPad Unit Price } \\
\text { \$US }\end{array}$ \\
\hline Apple & 150 & 35 & 150 & 25 & 106 \\
\hline $\begin{array}{l}\text { Assembly by Foxconn } \\
\text { Suppliers head- } \\
\text { quartered in core } \\
\text { countries (US, EU, }\end{array}$ & 24 & 6 & 1 & 3 & 8 \\
\hline $\begin{array}{l}\text { Japan) } \\
\text { Suppliers head- } \\
\text { quartered in semi- } \\
\text { peripheral countries } \\
\text { (Korea, Taiwan, }\end{array}$ & 59 & 54 & 32 & 22 & 13 \\
\hline Singapore) & 175 & 21 & 37 & 7 & 12 \\
\hline $\begin{array}{l}\text { Suppliers head- } \\
\text { quartered in China } \\
\text { Totals }\end{array}$ & 17 & 18 & $\begin{array}{c}3 \\
238\end{array}$ & 6 & $\begin{array}{c}1 \\
140\end{array}$ \\
\hline
\end{tabular}

Sources and Notes: Column A shares are derived from analysis of iPad teardown data and extensive Internet searches for iPad component pricing. In Columns B and D, the 2010-2011 GPMs and OPMs of Apple and its core/semiperipheral iPad suppliers are derived from corporate and/or investment brokerage websites. The share of Chinese suppliers is an estimate derived from analysis of data in Dedrick et al. (2009: 81) and estimates of the costs of local uncounted inputs in the assembly of Nokia phones (Ali-Yokko et al. 2011). Grouped GPMs and OPMs for core and semiperiphery are averages of supplier headquarters weighted by the cost of the components supplied. Column C is calculated by multiplying Column A by Column B, with the exception of Apple (GPM is based on the wholesale price). Column E is calculated by multiplying Column A by Column D. Contact the author for a list of the iPad suppliers. Numbers are rounded.

A much stronger measure of differential degrees of monopoly is the corporate operating profit margin (OPM), which is the proportion of a company's revenue that remains after all costs are paid, including direct production costs (labor, material inputs), indirect production costs (managerial and professional salaries, factory operational expenses), and corporate headquarter costs (general and administrative expenses, marketing expenses, product design, research and development, supply chain management, infrastructure expenses and depreciation, taxes and interest on debt). As shown in Table 2, Apple's OPM (25\%) reflects its high degree of monopoly 


\section{Journal of World-Systems Research}

in regard to governance of the supply chain, but other core firms do almost as well (22\%). ${ }^{16}$ In contrast, suppliers headquartered in Korea, Taiwan and Singapore average an OPM of 7 percent, and the assembler's OPM is only 3 percent. As Column E shows, Apple's OPM share of each iPad is $\$ 106$, but the total profit accruing to semiperipheral Asian firms is $\$ 21$, of which only one dollar is retained in mainland China. For each iPad, the total OPM share for these firms is lower than direct labor costs of $\$ 33$ (Table 1) and one-fifth of Apple's OPM share, a much worse ratio than for the GPMs. Asian suppliers do not achieve such low profit shares because they are located in the semiperiphery or because they are small. Rather they suffer from their disadvantageous relationship with a monopsonistic core firm.

Even though I have just used profit rates as an indicator, degrees of monopoly are, in practice, established in several ways. Apple constructs its supply chains to insure that it will retain a stronger degree of monopsony than its suppliers, even though some of them are larger corporations. First, it is important to emphasize that degrees of monopoly are not determined by corporate size. When iPad production began, its assembler and three of its Tier 2 suppliers were larger corporations than Apple, and four of its Tier 2 suppliers ranked in Fortune's Global 500. In 2011, Apple ranked 111 in the Global 500 while one of its key suppliers (Samsung) ranked 22, and the iPad assembler (Foxconn) ranked 60. ${ }^{17}$ How then has Apple constructed such a strong degree of monopoly? In the case of the iPad, Apple's degree of monopoly lies in its track record at:

1. designing innovations that attract a wide share of the global market,

2. controlling intellectual property rights,

3. governing the commodity chain through oligopolistic relations with suppliers,

4. control of product distribution and marketing, and

5. externalization of costs to suppliers.

Apple's Degree of Monopoly through Product Innovation and Design. Within worldsystems analysis, Arrighi and Drangel (1986: 19) emphasize the importance of a firm's innovation to its establishment of a monopolistic position in a commodity chain. In this way, innovative design has led to Apple's technological primacy. Many technical specialists celebrate Apple as "the Rolls Royce of the technology and design world," claiming that the company pioneered "features of standard operating systems and computer systems" and "reinvented the design standards" (Hangen 2012). On the one hand, the company has developed new computer operating systems and new technologies by combining existing and new components and processes into an original patented commodity. On the other hand, Apple's designs are shaped by

\footnotetext{
${ }^{16}$ Four of the core-based firms exceed Apple's profit rate, an indicator of their degrees of monopoly over small but essential components.

${ }^{17}$ Apple ranked 111 in Fortune's Global 500 largest corporations (by gross revenue). iPad suppliers that ranked in the Global 500 were Broadcom (343), Foxconn (60), LG Display (440), Qualcomm (222), Samsung (22), Texas Instruments (175), and Toshiba (89).

See http://money.cnn.com/magazines/fortune/global500/2011/full_list/ and http://money.cnn.com/magazines/fortune/global500/2013/full_list/.
} 
knowledge of the availability and capabilities of its suppliers (Dedrick, Kraemer and Linden 2009). Apple designs its products for offshoring of engineering, management, production and assembly to subcontractors who can keep costs low. Moreover, Apple maximizes its degrees of monopoly through "a closed ecosystem" in which it "exerts control over nearly every piece of the supply chain, from design to retail store" (Satariano and Burrows 2011: 2).

By itself, innovation is not enough to cement degrees of monopoly. What Apple needs is a set of barriers to limit competition, as in the case of its design patenting and legal protection of intellectual property rights. In an interview with his biographer, Steve Jobs emphasized that the three most fundamental strategies of his business philosophy were "to innovate," to establish patent rights to protect designs and "to use litigation to maintain Apple's monopoly" with respect to those patents (Thompson 2012). In the public arena, Apple "is known for and promotes itself as actively and aggressively enforcing its intellectual property interests" (Wingfield 2012). Since 2005, Apple has been tied to 60 percent of all major electronics patent lawsuits (Wieland 2012). ${ }^{18}$ Furthermore, Apple has been accused of pushing beyond protection of its own innovations to "use the legal process to prevent others from innovating, by engaging in competition by litigation" (Wilcox 2011).

Apple's Degree of Monopoly through Supply Chain Governance. Satariano and Burrows (2011: 1-2) contend that "operations expertise is as big an asset for Apple as product innovation or marketing." Apple tightly governs a supply chain that provides it as great (perhaps greater) a degree of monopoly than does its product innovation. Accolades like "the genius of Apple's supply chain" and "world's best supply chain" have been applied to the corporate production network. Most analysts are convinced that Apple achieves profit margins (both gross and operating) that are much greater than most electronics companies because of operational advantage through the tactics in which it organizes, governs and polices its supply chain. Between 2008 and 2013, Gartner's Supply Chain Top 25 annually ranked Apple first because the judges were convinced that its high profits are due to its orchestration of a tightly managed global supply chain (Ellinor 2013).

Apple's supply chain takes the modular form (Gereffi, Humphrey and Sturgeon 2005) in which components and assembly are outsourced to separate subcontractors that are governed by the company's strict design standards. Moreover, Apple holds sufficient governance power that it can require quick response to design changes and to consumer demand (Dedrick, Kraemer and Linden 2009: 104). Apple's supply chain management involves turnkey governance in which the outsourcing firm maintains "thick" information flow and close supervision of the design to production process (Sturgeon and Lee 2005). For example, Apple engineers "sometimes spend months living out of hotel rooms in order to be close to suppliers and manufacturers, helping to tweak the industrial processes that translate into mass-produced devices" (Satariano and Burrows 2011: 2).

The point of this governance system is to obtain a high degree of monopsony, the ability to mark down costs beyond what would be possible in a purely competitive system. In Braudelian terms, Apple acts as an "anti-market" player to exploit a chain of "market" players who are vulnerable because of their competition with each other. Because bargaining power is shifted to the buyer/financier, the supplier has limited control over price-setting and profit-taking

\footnotetext{
${ }^{18}$ For an overview of Apple litigation, see http://en.wikipedia.org/wiki/Apple_Inc._litigation.
} 


\section{Journal of World-Systems Research}

(Robinson 1993). Apple generates inter-firm competition among potential suppliers and leverages that situation to its advantage. It promotes competition among suppliers by contracting with several producers of the same components, by constantly searching for alternative subcontractors, and by threatening to terminate suppliers who do not comply. Consequently, the rate of exploitation of capitalists by capitalists is high, and the value of the producer's contribution to output is far greater than the price received.

Why would suppliers concede to Apple's demands? According to a small Taiwanese supplier,

A contract with Apple can send a supplier's stock share soaring or even represent most of its revenue. But working with Apple is not easy. Its engineers are uncompromising and it imposes a code of silence enforced with financial penalties for product leaks. And its history of cutting suppliers in a heartbeat helps create a "love-hate relationship" between Apple and the companies that build its products.... Still, when the world's undisputed leader in consumer technology comes calling, company executives often order their engineers to work around the clock (Boudreau 2012: 2).

In addition to its corporate culture of secrecy (Thomke and Feinberg 2010), Apple extends credit/financing to some key suppliers in exchange for long-term commitments (Satariano and Burrows 2011). Financial advances place a producer in a dependent, exploitable position because it permits Apple (1) to obtain material inputs and labor at below market prices, (2) to shift more of the risks and costs to producers, and (3) to capture labor and outputs over a longer term.

Apple's Degrees of Monopoly in Marketing. All the mechanisms for obtaining degrees of monopsony in production generate no super-profits unless the firm holds a high enough degree of monopoly in marketing to pass high price markups onto consumers. ${ }^{19}$ While Apple has played a strategic role in constructing brand recognition (not to mention cultish fetishism) for its products (Thomke and Feinberg 2010), key independent actors have reinforced its degree of monopoly in marketing. Some university business schools and investors idealize Apple as "an iconic brand, as well as a Wall Street darling" (Thomke and Feinberg 2010; Yoffie and Kim 2011; Zeiler 2012). Since their assessments are not precisely factual, technology specialists and business journalists help to construct a degree of monopoly for Apple by withholding such mythological acclaim from its competitors. Despite widespread criticism of its labor and ecological practices between 2008 and 2013, Fortune awarded Apple the number one spot in its list of the "World's Most Admired Companies."

Between 2000 and 2013, Apple developed a national and global market position that reflects a stronger degree of monopoly than any of its competitors. Between 2008 and 2012, Apple received the annual CMO Survey Award for Marketing Excellence, and business journalists point to three approaches that give Apple a degree of monopoly in comparison to the marketing strategies of competitors. First, Apple has built its own "marketing moat" through 407

\footnotetext{
${ }^{19}$ Here I am influenced by Marx's (1858) discussion of the realization process.
} 
stores in fourteen countries that sell only Apple products, thereby allowing a higher markup than received through wholesaling. Carefully recruited and trained sales associates are described as "customer-obsessed" in their abilities to interpret how customers will react (Wathieu 2010). The degree of monopoly that Apple achieves through such marketing strategies is reflected in its success. Its stores exhibit the highest retail sales per square foot among U.S. retailers, netting \$12 profit per visitor per quarter and average annual revenue per store of \$52 million (Dediu 2013). Second, Apple's products "are communicated to customers through novel and provocative advertising" that emphasizes a renegade, nonconformist image (Moorman 2012). Apple's marketing strategies are couched around the notion that consumers can have a "love affair with the only company that can make technology cool, relevant and transformative." 20 Third, Apple has developed a "hardcore fan base" (Hangen 2012), partially through "rumors and clearlydeliberate leaks about future products" that establish public perception of Apple as a customeroriented innovator (Wilcox 2012).

By underpricing its competitors, a lead firm like Apple can use the cumulative benefits of the serial monopsony power within the commodity chain it governs to enhance its degree of monopoly in its sales market. Dialectically, it is just such monopoly power that increases that firm's monopsonistic ability to exploit subcontractors. Many of the mechanisms to exploit subcontractors are designed to maximize dark value accumulation.

\section{Apple's Monopsonistic Externalization of Costs}

Up to this point, I have focused on the visible strategies that Apple employs to ensure high accumulation of bright value. However, I argue that Apple's profits are just as (if not more) dependent on strategies through which costs are externalized to accumulate unreported dark value. Through its supply chain governance, Apple utilizes its degrees of monopsony to externalize as many costs of production as possible to suppliers and, thereby, to extract dark value from them. All the suppliers in the iPad supply chain obtained their position by providing components that exceed their competitors in meeting Apple price, quality and design standards. Either they controlled some patent rights significant to production (e.g., Samsung), or they sell at near-cost for the sake of revenue through sheer volume (e.g., Foxconn), or they hope for better future outcomes (i.e., some of the smaller Tier 2 and 3 firms and most of the Tier 4 and 5 firms). In all these cases, firms are driven to cut costs. To do so, they must expand their financial margins by darkening the accounting system through the externalization of costs. Indeed, this Apple commodity chain achieved a quantum leap in such externalizations. Suppliers pass on to Apple the dark value embedded in their capture of low-paid labor power, low-cost natural resources, and the externalization of costs to ecosystems and households. Indeed, a common feature shared by most of the suppliers is their expertise at finding and maximizing cheap inputs and at externalizing costs (see later discussion). Monopsonistic chain governance is intended to structure the flow of dark value to the lead firm, Apple.

${ }^{20}$ See www.marketingapple.com (23 January 2013). 


\section{Journal of World-Systems Research}

\section{Apple's Dark Value Extraction}

At every node of the chain, dark value arises from the "dark energy" of low-paid and unpaid labor and natural resources. By the time a commodity has gone through numerous nodes of a global chain to arrive at the doorstep of the consumer, it has incorporated not only the embedded inputs of Marx's (1993, vol. 1) paid labor power but also massive amounts of under-paid and unpaid labor and ecological inputs. My argument is that capitalism is dependent upon, even driven by, a micro-structure of "dark energy" in the form of such externalities. Since these factors never appear in the accounting of production costs, they are invisible "gifts" to capitalists and to buyers. These concealed subsidies bubble up the commodity chain to keep the price of the finished product more appealing to the budgets of distant richer consumers. In the sections that follow, I will explore the ways in which the iPad commodity chain is grounded in the extraction of dark value from (a) waged and salaried laborers, (b) from unpaid household labor, (c) from informal sector labor, and from (d) unpaid ecological externalities.

\section{Apple Exploitation of Chinese Migratory Workers}

In the neoliberal era, core deindustrialization has been stimulated by labor arbitrage, the global search for lower-waged labor to produce items to be sold at high prices in distant zones where wages are higher (Roach 2004). After the initiation of "capitalism with Chinese characteristics" in 1978 (Huang 2008), China doubled the size of the world-system's working class over two decades. This project is an historic combination of development by means of (a) a vigorous program for attracting foreign direct investment, (b) expansion of export-oriented industries, and (c) the semi-proletarianization of its rural surplus labor, following the path advocated by Arthur Lewis (1954).

China's labor-intensive industrialization is disproportionately supported by the country's most vulnerable class of workers who are recruited from rural areas. ${ }^{21}$ Apple suppliers keep wages low because of China's intentional construction of a segmented labor market (the hukou system of household registration) in which migratory temporary peasant workers are legally and structurally inferior to urbanites (Pun and Huilin 2010). These migrant workers are classified as nonresidential workers who form a "split labor market" (Bonacich 1972) of lower-paid temporary workers with few legal rights (Selden and Jieh-min 2011: 4). "Without social insurance and labor rights infrastructure, the migrant labor regime is a safe haven for urban and industrial employers that thrive on cost-minimization" (Fan 2004: 288). This "floating population" makes up 70 percent of manufacturing workers, is paid wages below national averages, works 50 percent longer hours than other urban laborers, and is concentrated in massive industrial compounds that usually deduct from wages the cost of housing, food and health services (Foster and McChesney 2010).

\footnotetext{
${ }^{21}$ Until recently, a majority of workers were young women (Pun 2007). In the case of iPad assembly by Foxconn, two-thirds are young males (Fair Labor Association 2012). However, I have been unable to find gender ratios for Tier 2 and 3 suppliers.
} 
Apple is quite aware of the concealed value that it captures through exploitation of migratory workers by its suppliers. In line with its Supplier Code of Conduct (Apple 2005: 1), Apple conducted audits of 356 of its suppliers in 2010 and 2011, documenting wages lower than government standards, delayed payment of wages, wage deductions to discipline workers, and failure to pay overtime. With respect to worker wages and benefits, Apple documented that 2.6 times more suppliers were in violation of corporate standards in 2011 than in 2010. Interviews with former Apple executives explain the lack of corporate willingness to implement strategies to improve labor conditions. Commitment to increase worker income "falters when it conflicts with crucial supplier relationships or the fast delivery of new products." Labor exploitation continues because "the system works" for Apple, and "a radical overhaul would slow innovation" (Duhigg and Barboza 2012: 4). ${ }^{22}$

Between 2010 and 2012, NGOs and media heavily criticized Foxconn assembly factories (Duhigg and Barboza 2012; Fair Labor Association 2012) while ignoring the labor forces in the other tiers of the iPad supply chain. Such public preoccupation with Foxconn assembly creates a smoke screen for the cheap labor philosophy that pervades Apple's supply chain. China Labor Watch (2012b: 1) points out that multinational electronic manufacturers treat labor as the elastic factor of production. "Because most production costs, including distribution and physical materials, are to a great extent inelastic, the only way factories are able to offer a competitive advantage is to lower... labor costs" (Lin 2004: 180). Apple suppliers employ several strategies to lower costs below officially-recorded wage rates. First, workers are kept in probationary status in order to evade government regulations about wage increases. Second, a laborer who fails to meet the daily production quota is often required to complete the work after regular hours without pay. Third, disappearance of pay slips and under-reporting of work hours is common (Fair Labor Association 2012). Fourth, many workers are subject to a "dormitory labor system" in massive company towns (Pun 2007) where they are daily subjected to several forms of unpaid labor extraction (Fair Labor Association 2012; China Labor Watch 2012a).

\section{Dark Value from Undercompensated Waged Labor}

In Table 3, we move from the bright value analyzed in Tables 1 and 2 to the dark value that is embedded in the iPad commodity chain. Dark value is estimated by comparing actual production costs with estimated "negative opportunity costs" of production in the United States. In Column $\mathrm{B}$, dark value is derived from the multiplier effect embedded in the wage compensation differentials (Bureau of Labor Statistics 2010) among the various countries in which the lead firm and its outsourced suppliers are situated. Indeed, the wage gap is much greater than it appears at first sight. Most core workers receive compensation beyond direct wage payments (e.g., health and retirement benefits) that are worth more than half of the basic wage. Chinese workers producing the iPad receive no such benefits, a major basis for its cheapness. It is the context of comparative compensation in which we can most clearly see the interconnectedness of unequal exchange and dark value. Basic to the theory of unequal exchange is the claim that wage inequalities cannot be explained away by differences in productivity. Simply put, iPad workers

\footnotetext{
${ }^{22}$ In 2012, Apple Corporation commissioned the Fair Labor Association (2012) to investigate working conditions at Foxconn's Chinese factories. Apple (2013) agrees with much of that report and adds additional information about some forms of labor exploitation.
} 


\section{Journal of World-Systems Research}

are not paid less because their productivity is lower than that of core workers. Indeed, the cheaper workers are probably more productive. This Apple supply chain is grounded in labor practices and productivity standards that exceed or equal those that would occur in the core. First, assembly or component manufacturing must meet strict quality standards set by the lead firm to achieve a designated design. Second, suppliers in the first two tiers of the supply chain are world leaders in productivity, as suggested by earlier information about their rankings in the Global 500. Third, workers in the first two tiers employ state of the art technology. Fourth, managerial personnel drive these workers through Taylorist speedups, shift quotas and longer work weeks that are not legally tolerated in the core. Suppliers organize schedules to intensify worker productivity, with daily shifts of twelve hours and tight speedup supervision being routine (SACOM 2011: 8-9). Work weeks surpass sixty hours because workers are required to work overtime hours that exceed legal regulations (Fair Labor Association 2012).

Table 3. Partial Accounting of Dark Value in the First Generation iPad Supply Chain, January 2010 - March 2011

\begin{tabular}{|c|c|c|c|c|}
\hline Basis & $\begin{array}{c}\text { A } \\
\$ \text { Cost per Unit }\end{array}$ & $\begin{array}{c}\text { B } \\
\text { U.S. Multiplier }\end{array}$ & $\begin{array}{c}\mathrm{C} \\
\$ \text { Cost if produced } \\
\text { in U.S. }\end{array}$ & $\begin{array}{c}\text { D } \\
\text { \$ Dark } \\
\text { Value }\end{array}$ \\
\hline \multicolumn{5}{|c|}{ Part A. Dark Value Extractions from Waged Labor } \\
\hline Tier 1: Assembly & 8 & 14 & 112 & 104 \\
\hline \multicolumn{5}{|l|}{ Tier 2: Production of Major } \\
\hline Components & 25 & Range: $2-12$ & 246 & 221 \\
\hline Tier 3: Production of Subcomponents & 12 & Range: $2-12$ & 84 & 72 \\
\hline Totals & 45 & & 442 & 397 \\
\hline \multicolumn{5}{|c|}{ Part B. Dark Value Extractions from Professional, Managerial, and Indirect Production Costs } \\
\hline Tier 1: Assembly & 5 & 8 & 40 & 35 \\
\hline \multicolumn{5}{|l|}{ Tier 2: Production of Major } \\
\hline Components & 20 & Range: $3-8$ & 123 & 103 \\
\hline Tier 3: Production of Subcomponents & 10 & Range: $3-8$ & 47 & 37 \\
\hline Totals & 35 & & 210 & 175 \\
\hline \multicolumn{5}{|c|}{ Part C. Totals for Both categories of Workers } \\
\hline All Workers & 80 & & 652 & 572 \\
\hline
\end{tabular}

Sources and Notes: iSuppli estimates the direct labor cost of assembly in China at \$9. Some experts (Lasky 2010; Dediu 2012) contend this is a serious under-estimation. I estimated the average 2010 Foxconn assembly worker's wage as $\$ 1.50$ per hour (zero benefits) or $\$ 3,000$ per year (Economix Editor 2010). This estimate is high since it was based on the Foxconn Shenzen complex rather than to the inland Chengdu plant where most iPads are assembled at much lower labor costs. The U.S. rate is "the median expected salary for a typical Electronics Assembler I": $\$ 29,000$ basic wage plus $\$ 16,000$ in benefits, thus $\$ 45,000$ per year (Salary Wizard 2013). I adjusted this estimate downward to \$42,000 to account for raises since 2010, thus $\$ 21$ per hour, arriving at a multiple of 14. The salaries of managers and engineers involved in production are "indirect production compensation" that encompasses about 40 percent of gross profit margin (Miller and Vollman 1985). The indirect production compensation measure is based on the assumption of three-quarters Chinese engineers. The multipliers are derived from Linden et al. (2011: 229). Column D is calculated by subtracting Column A from Column C. For details about calculation and methods for Tiers 2 and 3 , see Appendix, Table 6. Numbers are rounded.

The waged labor costs for Tiers 1, 2 and 3 of iPad suppliers (see Figure 1) were $\$ 45$ per unit (Table 3, Part A). Assembly labor (Tier 1) is separated out because of widespread discussion of the possibility of returning this last production stage to the United States (e.g., Goldman 2012; Diedrich 2013). By application of a reasonable multiplier for assembly, I demonstrate that the dark value from assembly labor is equal to the iPad operating margin (see Table 1). The most 
significant input of dark value from labor is in the manufacture of major components by Tier 2 and 3 suppliers, reflecting the vast gap between the wages of Asian and core workers. Moreover, most of the Tier 2 component manufacturing is done in China at a cost of \$196 less than it could be accomplished in the United States. Thus, the dark value extracted from Tier 2 labor is $\$ 221$, and an additional $\$ 72$ of dark value is expropriated from Tier 3 labor. $^{23}$

At a 2011 White House dinner for CEOs, President Obama asked Steve Jobs, "What would it take for Apple to bring its manufacturing home?" The Apple CEO replied: "Those jobs aren't coming back" (Duhigg 2012). These empirical data help us understand Jobs' response to the President. Bringing iPad assembly and production to the United States would eliminate Apple profits and/or raise the iPad retail price significantly. The Apple success story of design innovation is dwarfed by the financial significance of its capture of underpaid waged labor. Whatever the value created by design, it can hardly match the significance of cheap labor. The waged workers in the top three tiers of suppliers add \$397 of embedded dark value to each iPad. Without those inputs, Apple's \$106 operating profit margin would not be possible because the hidden savings from cheap labor is nearly four times greater. ${ }^{24}$

\section{Dark Value from Salaried Workers}

Apple benefits from a second category of underpaid Asian laborers who are not visible in the direct labor costs reported in Table $1 .{ }^{25}$ To assess the full labor cost, we need to take into account the professional and managerial workers (including cheap Asian engineers) who organize, supervise and provide administrative support services to the waged labor forces. Although much lower than that extracted from waged workers, the dark value generated by cheap managerial and engineering labor remains significant. Even though these costs nearly match wage compensation to production workers, very few researchers analyze the savings generated from the efficiency and low remuneration of these workers. Therefore, I faced the daunting task of determining how to develop estimates about these labor cadres. To my surprise, I discovered that these salary costs are hidden in the gross profit margin. Miller and Vollmann (1985) and Tu and Zhang (2010) provide leads in their breakdowns of overhead costs included in gross margins. They indicate that about 40 percent of the gross margin is allocated to these "indirect production salary costs." Thus, I applied this ratio to the gross margins for Tier 1 and 2 firms (Table 1) to arrive at a measure of the payments to these workers at production sites. I then estimated that three-quarters

\footnotetext{
${ }^{23}$ A small part of this dark value is supplied by workers in South Korea, Taiwan and Singapore, so non-Chinese components of dark value also contribute to unequal exchange. This relatively small Tier 3 amount reflects the degree to which earlier production is based in Korea and Japan. For a breakdown, see Table 7, Appendix.

${ }^{24}$ The Fair Labor Association (2012) reports several forms of unpaid labor that are stolen from these waged workers. However, I have not attempted to estimate the additional dark value of such theft. For an extended discussion of these forms of unpaid labor, see http://filebox.vt.edu/users/wdunaway/Clelland/SurplusDrain/Missing.pdf. If I could quantify a value for those unpaid labors, the full accounting of dark value would be much higher.

${ }^{25}$ See Appendix for methods used to estimate this form of indirect production costs and its related dark value. Previous Apple supply chain research (Kraemer, Linden and Dedrick 2011) failed to take these workers into account. The salaries of the managers, engineers and supervisors in factories are not reported by accountants with direct labor costs but are included in the gross profit margin. Many academic studies render these workers invisible by integrating them in the category of "indirect production costs," a component of GPM. Linden, Dedrick and Kraemer (2011) is a rare exception.
} 
of these payments (about 30 percent of gross margins) was paid to local supervisors, managers and engineers. ${ }^{26}$ Table 3 (Part B) shows that the cost per unit (\$35) added by these salaries is 78 percent of the wages paid to a much larger labor force of production workers (\$45). Moreover, my conservative estimate of dark value benefits of $\$ 175$ per unit is an indicator of the economic significance of these workers. These "hired-hand" capitalists are proficient at (a) organizational efficiency and time management, (b) problem solving, (c) recruiting cheap waged workers, (d) expropriating hidden unpaid labor from them, and (e) and speeding up worker productivity. Moreover, they are quite effective at externalizing costs that squeeze downward the profit margins of lower-tier suppliers. While cheap in Asia, the dark value of their work at U.S. rates exceeds Apple’s operating profit margin per iPad by $\$ 69 .{ }^{27}$

Combined, the dark value embedded in all iPad labor costs is a stunning \$572, an amount that exceeds the retail price and is five times greater than Apple's operating profit margin. If these hidden costs were paid, the price of an iPad would double, vastly diminishing Apple profits from a more limited consumer base. Consequently, Apple's Jobian innovation nirvana means little without cheap labor. The company's degrees of monopoly at maximizing Chinese dark labor value are as crucial as innovation to its ranking as the second most profitable company in the Fortune Global 500.

\section{Dark Value from Unpaid Household Labor}

Behind the vast army of the low-paid world labor force is an even larger network of unpaid support workers. World-systems scholars have emphasized the centrality of unpaid household labor to the world-economy, and feminist economists have exerted much effort to measure the economic value of women's unpaid household labor (Beneria, 1999). ${ }^{28}$ While Marx (1993, vol. 1: 176) claimed "the secret of profit making" lay in exploitation of waged labor that occurred in the hidden abode of the factory, we commodity chain analysts need to enter the hidden abode of labor reproduction, the household, to find that secret. The starting point of a commodity chain is the extraction of surplus from unpaid household work, and that unpaid labor contributes to the "expanded value" of a commodity at every production step in the chain. The household reproduces and partially provisions itself, allowing waged labor to be generated for the capitalist below its paid costs (Mies et al. 1988). Hidden unpaid household labor is embodied in every waged laborer. In other words, the household provides vast benefits for each employer within a commodity chain. Thereby, all the capitalists that exist within the full span of a commodity chain extract from thousands of households the production of this unpaid value, but they conceal its embodiment in the finished product.

\footnotetext{
${ }^{26}$ The method for estimating Tier 3 costs is found in notes for Table 7, Appendix.

27 One-quarter of indirect production salary costs is paid to managerial workers on assignment from firm headquarters to work abroad. There is a lower multiplier for these cheap salaried workers because much of this work is done by Koreans and Taiwanese professionals, and the Chinese engineers are relatively less exploited than wage workers. See Appendix, Tables 6 and 7 for details.

${ }^{28}$ For foundational world-systems background, see Review: vol. 3 (2), vol. 5 (3), vol. 7 (2), Smith et. al. (1984), and Smith and Wallerstein (1992). For recent scholarship about household linkages to commodity chains, see Dunaway $(2012$, 2014). See Clelland (2014) for analysis of the dark value of household labor in a coffee commodity chain.
} 
Table 4. Underpaid and Unpaid Externalities in the iPad Supply Chain (China Only)

\begin{tabular}{|c|c|c|c|}
\hline Basis & $\begin{array}{c}\text { A } \\
\$ \text { Cost per Unit }\end{array}$ & $\begin{array}{c}\text { B } \\
\text { U.S. Multiplier }\end{array}$ & $\begin{array}{l}\text { C } \\
\text { Dark Value: \$ Cost } \\
\text { if produced in U.S. }\end{array}$ \\
\hline \multicolumn{4}{|c|}{ Part A. Household Labor Externalities } \\
\hline Household Production of Labor & 7 & 9 & 63 \\
\hline \multicolumn{4}{|l|}{ Daily Household Unpaid } \\
\hline Reproduction Costs & 12 & 9 & 108 \\
\hline Total & 19 & & 171 \\
\hline \multicolumn{4}{|c|}{ Part B. Underpaid and Unpaid Informal Sector } \\
\hline \multicolumn{4}{|c|}{ Part C. Unpaid Ecological Externalities } \\
\hline Pollution Externalities & 19 & 10 & 190 \\
\hline
\end{tabular}

Think of human labor power as a material good that must be (re)produced like any other commodity. But how can we measure the value for capitalists and consumers of the dark energy involved? For estimates of household labor production in China, I began by assuming that the worth of the labor time in raising a child to worker status is at least that of the minimum wage (\$0.80 per hour). Then, I assume that an extended household spends twenty unpaid hours a week in this endeavor, worth half of a weekly minimum wage. Next, I add one-quarter of the household income of two minimum wages as child-rearing expenditures, once again worth half a minimum wage. These two factors total to one minimum wage, which is more than 2,000 hours or at least $\$ 1,600$ per year. If costed over fifteen years (many Chinese children end schooling at that age and enter formal work), the unpaid benefit to the employer of this free human capital is $\$ 24,000$. If the producers of this human capital were remunerated without interest over a 40 year work life for this labor commodity, they would receive a payment of $\$ 600$ per year. Assuming an average wage of $\$ 2$ per hour or $\$ 4,000$ per year, each year of labor is a provision of a 15 percent dark value bonus to the employer. I applied this ratio to the total Chinese labor costs embedded in an iPad. ${ }^{29}$ In Table 4 (Part A), I conservatively estimate that the unpaid cost of household production of Chinese labor is about $\$ 7$ per Apple iPad. Since the human production of the same amount of labor power in the core would be worth at least nine times more, the dark value for Apple and the core consumer is expanded to $\$ 63{ }^{30}$

In addition to these forms of labor reproduction, dark value is extracted through the household provisioning that subsidizes low and erratic wages (Dunaway 2012). How might the value of this dark energy be measured? For estimates of household unpaid reproduction

\footnotetext{
${ }^{29}$ I drew data from Table 1 (Tier 1), Table 3 (Tier 2), and Table 7 (Tier 3).

${ }^{30}$ This number would more than double if we added dark value estimates for Korea and Taiwanese unpaid labor production, plus that embedded in Tiers 4, 5 and 6 .
} 
externalities in Part A, I began with Qi and Dong (2013: 27) who report thirty hours per week of unpaid work (two-thirds by females) in Chinese households. Because of the widespread use within the Chinese export-oriented commodity chains of "the dormitory labor system" (Pun 2007), I assumed that many workers in the iPad commodity chain live in company dorms and are independent from the unpaid reproductive support of households (i.e., they are more fully proletarianized than is usually the case). For that reason, I conservatively reduced the estimate of the hours of unpaid household labor by one-third (to 20 hours weekly per household). In contrast to the standard variety of higher valuation measures for unpaid household work (Budlender 2002), I use the Chinese minimum wage, which is roughly half the average wage. Thus, my conservative estimate of unpaid daily reproduction cost is one-quarter of the estimated wage/salary costs (one-half the wage times one-half the official work week). As a result, I estimate that there is $\$ 12$ of unpaid household reproduction costs embedded in each iPad. Since this labor power would cost nine times more in the core (using the U.S. minimum wage as the multiplier), the dark value for Apple and the core consumer is expanded to $\$ 108$. Combined, there is $\$ 171$ worth of unpaid household labor embedded as dark value in each iPad, an amount that exceeds Apple's gross profit margin.

\section{Dark Value from Informal Sector Labor}

The economic significance of the informal sector has been recognized by world-systems scholars (Portes 1983; Tabak and Crichlow 2000) and by mainstream international development organizations (International Labour Organization 2001; United Nations 2003). Dark surplus drains from informal sector labor feed into all commodity chains. These supply chains are "invisible" because capitalists and consumers seek to deny that they are beneficiaries of surpluses extracted from semi-proletarianized workers who are concentrated in the informal sector (Tabak and Crichlow 2000). Informal sector workers subsidize global commodity chains through exchanges in which their labor time is under-valued. On the one hand, they pass dark value through goods and services that are embedded into the production processes of commodity chains. ${ }^{31}$ On the other hand, these hidden workers provide local dark value to low-paid waged workers who, in turn, embed that dark value into the export commodities they manufacture. The daily life of the peripheral wage earner entails unequal exchanges in which one hour's earnings are used to purchase goods or services that require greater labor time from cheaper producers. At iPad factories, Asian workers expand their income by purchasing cheap meals, goods and services from lower-paid informal sector vendors that ply the streets near their factories (Pun and Chan 2012).

How might we estimate the value of these hidden externalities? I began by deriving key information from previous studies. For the United States, Baker and Lee (1993) and Blivens (2003) identify the modal estimate of the employment "respending multiplier" tied to paid labor as 50 percent of the spender's wage. In Tiers 1 to 3 of the commodity chain, approximately $\$ 48$ is paid to Chinese waged and salaried workers out of the total cost of an iPad. Because of the

\footnotetext{
${ }^{31}$ Such informal sector inputs are documented in a limited fashion for Chinese iPad factories (China Labor Watch 2012a, 2012b; Pun and Chan 2012).
} 
extraordinary high savings rate in China, I reduced to 33 percent the income multiplier that funds extended employment. Consequently, the $\$ 48$ paid out to Chinese iPad laborers generates another \$16 payment to other Chinese workers. However, these laborers are situated in the informal sector, earning about the minimum wage, or about one-half the country's average manufacturing wage. In buying the labor power of these underpaid workers, the Chinese purchaser receives a 100 percent bonus in dark value. This bonus is a capture of local dark value from the hidden sub-economy of Braudel's "material life," and it is a necessary pillar of waged work in the market economy. In this way, the underpaid labor power of cheaper support work is embedded in the iPad, now as globalized dark value. By applying the minimum wage ratio between China and the United States as a multiplier, we see that $\$ 144$ of veiled value is added to the iPad. Even though most scholars would consider them to be outside the commodity chain, the savings from the unpaid services of this Chinese underclass contributes dark value to that chain that is nearly equivalent to Apple's gross profit margin for each iPad.

\section{Dark Value from Ecological Externalities}

Ecological degradation and depletion comprise a significant array of externalities through which Apple suppliers extract dark value. Each iPad uses 33 pounds of minerals (some of which are rare and limited in supply), 79 gallons of water and enough fossil-fuel based electricity to generate 66 pounds of carbon dioxide (Ecolibris 2012). Moreover, the first generation iPad generates 105 kilograms of greenhouse gas emissions (Apple 2011b). Apple has been attacked for failing to alleviate numerous environmental problems throughout its Asian supply chains (China Watch 2012a; Ecolibris 2012; Friends of Nature 2011). A comparison of Apple (2011a, 2013) factory audits in 2010 and 2012 shows little or no improvement with respect to supplier management of hazardous substances, wastewater, air emissions, solid waste, or required governmental environmental permits and reporting. Moreover, Asian NGOs accuse Apple suppliers of causing chemical emissions, heavy metal discharges, air pollution, and water degradation that endanger the lives of people in areas adjacent to factories. NGOs also pinpoint worker exposure to hazardous substances that cause life-threatening illnesses and cancers (Friends of Nature 2011).

Unfortunately, there are no studies of the monetary value of such ecological costs. In order to obtain a rough measure, I began with the World Bank (2007) estimate that the total cost of air and water pollution in China is 5.78 percent of the GDP. ${ }^{32}$ Since the electronics industry is an extremely heavy polluter and ecological cleanup is highly expensive, I assumed that the percentage cost of pollution per iPad would be greater than that found for the GDP, or roughly 9 percent. Multiplying that ratio by the costs of production in China (\$207) leads to an estimate of $\$ 19$ per unit (reported in Part C, Column A). ${ }^{33}$ To estimate what ecological cleanup would cost at

\footnotetext{
${ }^{32}$ I arrive at a very conservative estimate because several types of ecological degradation are not covered by this World Bank estimate.

${ }^{33}$ This estimate is conservative as it is based only on production in Tiers 1 and 2 . The figure represents the share of the factory price (\$275 in Table 1) of the components produced in China. I have not estimated the unpaid environmental costs of the remaining $\$ 68$ worth of components produced elsewhere in Asia.
} 
U.S. rates, I employed a multiplier of ten. ${ }^{34}$ In Table 4 (Part C), I very conservatively estimate that the dark value savings to Apple of not paying for some ecological externalities is $\$ 190$ per iPad. This ecological unequal exchange (cf. Jorgensen and Rice 2012) is nearly double Apple's operating profit margin.

Table 5. Summary of Dark Value Embedded in Each iPad Unit

\begin{tabular}{|c|c|c|}
\hline Sources of Dark Value Extraction & US\$ Dark Value & \\
\hline Waged Labor & 397 & \\
\hline Professional, Managerial, \& Headquarters Office Labor & 175 & \\
\hline Labor Subtotal & & 572 \\
\hline Household Labor Externalities & 171 & \\
\hline Underpaid and Unpaid Informal Sector & 144 & \\
\hline Unpaid Ecological Externalities & 190 & \\
\hline Externalities Subtotal & & 505 \\
\hline Total & & 1,077 \\
\hline
\end{tabular}

Sources: Tables 3 and 4

\section{Conclusion}

The world-economy operates on a large base of unmeasured, uncosted and unrecognized dark energy. The task of economic elites is to transform a small portion of that dark energy into bright value that can be sold, accumulated and further expanded. However, much of the expended dark energy occurs in the forms of unpaid labor and uncosted externalities that are not transformed into bright value but are embedded in commodities as value beyond price that benefits consumers. Although commodity chains differ in specifics, this passage from dark energy to dark value is a basic component of all such chains. ${ }^{35}$ In this sense, such chains can be viewed $a s$ global dark value chains. I have examined the Apple iPad as an example of the ongoing incorporation of dark energy into a material commodity. The estimated total dark value embedded in each iPad is \$1,077 (see Table 5), an amount that is ten times greater than Apple's operating profit margin and more than twice the retail price (see Table 1). ${ }^{36}$

\footnotetext{
${ }^{34}$ I assume that the costs of pollution are roughly equivalent to cleanup costs and that the cleanup costs can be measured roughly in terms of wage/salary costs. This multiplier is the average of multipliers reported for waged workers and engineers in Table 6, Appendix.

${ }^{35}$ Dark value analysis can also be applied to countries, subnational regions and class hierarchies. For example, the Chinese household registration system generates a national class-based dark value system independent of its role in global commodity chains. See earlier discussion of migratory workers.

${ }^{36}$ My dark value estimates are quite conservative because so much of the commodity chain is still concealed from public view. The full calculation of dark value in any commodity chain would necessitate public transparency about transactions that capitalists keep deeply concealed. Capitalists do not intend for us to be able to demystify all the levels at which they benefit from costed and uncosted surpluses, for public revelation would diminish their capacity to extract dark value. Consequently, I have been unable to quantify a great deal of dark value that is embedded in the iPad, including public subsidies and costs externalized to rural communities and women. In addition, Apple externalizes numerous short-term and long-term costs to workers that are not captured in my dark value estimates.
} 
Even though such dark value is concealed from scholarly and accounting calculations of "value-added" and gross/operating profit margins, this real value is nearly 32 times greater than the total operating margin of all the capitalists other than Apple in Tiers 1 and 2 of the production chain (See Table 2). Apple's operating profit margin of $\$ 106$ (Table 2) can be explained by its ability to extract $\$ 572$ worth of dark value of cheap labor from its supply chain (Table 5), about the same as the bright value retail price. Without cheap labor, the retail price would double, possibly reducing profit to zero. The extension of the dark value concept beyond low-paid labor to include the informal sector, household labor and ecological degradation is meant to demonstrate the significance of unpaid externalities to commodity chains. The total value of these uncosted inputs is $\$ 505$ (see Table 5), an amount that is 3.4 times Apple's operating profit margin (see Table 2). Moreover, this embedded dark value exceeds the retail price (Table 1). Thus, we are enlightened about why Steve Jobs was confident that production will never return to the United States.

While I have focused on the Apple iPad commodity chain, it is important to recognize that the mechanisms of dark value drain that are manipulated so effectively by Apple are replicated in every global commodity chain. What the Apple iPad supply chain shares with other forms of export-oriented industrial commodity chains is its use of surplus labor to comparative advantage. Arthur Lewis (1954) would be astounded at the successful use of his model in China, going beyond selling surplus labor power at give-away levels. The Chinese state uses its monopolistic control of its labor surplus to provide a degree of monopoly to entrepreneurs who, in turn, sell this advantage to core capitalists. The scope of the sale of cheap labor is so great that it allows for both a large external surplus drain and a large semiperipheral accumulation, an historical economic precedent still under-theorized. It represents a new regime of global accumulation, but it has in common with previous core-periphery relations the gift of cheap labor. Apple's iPad price is based on this gift. It is the core of the Apple, and the core of the Apple is the historic core of the world-system: the drain of surplus from the (semi)periphery, largely through the drain of the value of labor power.

Like other capitalists, Apple gains its profits through the strong degrees of monopoly it garners from its design, production and marketing strategies. In addition, Apple extracts enormous levels of dark value that both widen profit margins and keep consumer prices low. Since Apple has the advantage of such dark energy, it can expand sales by applying a large portion of these unpaid production costs to lower prices. We should not underplay the wonders of the capitalist world-system for the workers in the core, and we should not underestimate the importance of the consumer surplus. ${ }^{37}$ Most dark value is passed on to distant consumers in the

For an extended discussion of the elements of dark value that I have not been able to include in these estimates, see http://filebox.vt.edu/users/wdunaway/Clelland/SurplusDrain/Missing.pdf.

${ }^{37}$ My argument is a radical variant of the neo-classical economic concept of consumer surplus. My use of the concept consumer surplus differs from most other scholars who focus on subjective utility, the difference between real price and what an individual would be willing to pay (see www.businessdictionary.com/definition/consumersurplus.html). My usage points toward the objective reality of the hidden value of unpaid costs to consumers. The passage of such a large proportion of dark value suggests that most analyses underplay the advantage of North-South trade to the core consumer. It is true, however, that this unrecorded advantage of consumer surplus is vaporous. It disappears with consumption, so it does not directly provide the advantage of bright value, i.e., availability for expanded investment. 
form of lower prices than would have been possible had production taken place in the core. This question arises: Does the transnational capitalist class, through the international division of labor, often provide more benefits for the core working and middle classes than it captures for itself? In the case of the iPad, most of the expropriated dark value is realized, not as corporate profit, but as consumer surplus in the form of cheaper goods. Consequently, the core citizen becomes an unwitting beneficiary of this exploitative system when (s)he uses one waged hour to purchase a product that embodies many more lower-waged and unpaid hours and many under-valued material and ecological inputs. In this manner, core citizens become a global consumerist aristocracy. ${ }^{38}$

\section{References}

Ali-Yokko, Jyrki et al. 2011. "Who Captures Value in Global Supply Chains?" Research Institute of the Finnish Economy, Discussion paper 1240.

Amin, Samir. 1976. Unequal Development. New York: Monthly Review Press. . 2003. "World Poverty, Pauperization and Capital Accumulation." Monthly Review 55

(5): $1-9$. . 2010. The Law of Worldwide Value. New York: Monthly Review Press.

Apple Corporation. 2005. "Apple Supplier Code of Conduct," www.apple.com. . 2011a. "Apple Supplier Responsibility: 2010 Progress Report," www.apple.com. 2011b. "ipad Environmental Report,”www.apple.com. 2012. "Apple Suppliers List, 2011," www.apple.com. 2013. "Apple Supplier Responsibility: 2012 Progress Report,” www.apple.com.

Arrighi, Giovanni. 1994. The Long Twentieth Century: Money, Power and the Origins of Our Times. London: Verso.

Arrighi, Giovanni, and Jessica Drangel. 1986. "The Stratification of the World-Economy." Review 10(1): 9-74.

Bair, Jennifer. 2009. "Global Commodity Chains: Genealogy and Review." In Frontiers of Commodity Chain Research, ed. Jennifer Bair. Stanford: Stanford University Press, 1-35.

Baker, Dean and Thea Lee. 1993. "Employment Multipliers in the U.S. Economy." Washington, D.C.: Economic Policy Institute, Working Paper 107.

Bannister, Judith and George Cook. 2011. "China's Employment and Compensation Costs in Manufacturing through 2008." Monthly Labor Review (March): 39-52.

Beneria, Lourdes. 1999. "The Enduring Debate Over Unpaid Labor." International Labour Review 138(3): 287-309.

Blivens, Josh. 2003. "Updated Employment Multipliers for the U.S. Economy." Washington, D.C.: Economic Policy Institute, Working Paper 268.

\footnotetext{
${ }^{38}$ This is a word play on the "aristocracy of labor" debate (Communist Working Group 1986; Cope 2012).
} 
Bonacich, Edna. 1972. "A Theory of Ethnic Antagonisms and the Split Labor Market." American Sociological Review 37(5): 547-59.

Boudreau, John. 2012. "Apple Taps Obscure Asian Suppliers to Bring the iPhone and Other Products to the Masses." Mercury News (26 September), www.mercurynews.com/business/.

Braudel, Fernand. 1981. Civilization and Capitalism, 15th to 18th Century. Translated by Sian Reynolds. New York: Harper and Row, 3 vols.

Brewer, Benjamin. 2011. "Global Commodity Chains and World Income Inequalities: The Missing Link of Inequality and the "Upgrading Paradox." Journal of World-Systems Research 17(2): 308-27.

Bureau of Labor Statistics. 2010. "International Comparisons of Hourly Compensation Costs in Manufacturing, 2011." U.S. Department of Labor, www.bls.gov/news.release/pdf/ichcc.pdf.

. 2013. "International Comparisons of Hourly Compensation Costs in Manufacturing Industries, 2011," www.bis.gov.ilc.

China Labor Watch. 2012a. "Beyond Foxconn: Deplorable Working Conditions Characterize Apple's Entire Supply Chain," www.chinalaborwatch.org.

. 2012b. "Tragedies of Globalization: The Truth behind Electronics Sweatshops," www.chinalaborwatch.org.

Clelland, Donald A. 2012. "Surplus Drain and Dark Value in the Modern World-System." In Routledge Handbook of World-Systems Analysis, eds. Salvatore Babones and Christopher Chase-Dunn. London: Routledge, 197-205.

2014. "Unpaid Labor as Dark Value in Global Commodity Chains." In Gendered Commodity Chains: Seeing Women's Work and Households in $21^{\text {st }}$ Century Global Production, ed. W. A. Dunaway. Stanford: Stanford University Press, 72-87.

Communist Working Group. 1986. Unequal Exchange and the Prospects of Socialism. Copenhagen: Manifest Press.

Cope, Zaki. 2012. Divided World, Divided Class: Global Political Economy and the Stratification of Labour Under Capitalism. Montreal: Kersplebedeb.

Dediu, Horace. 2012. "How Much Does It Take to Manufacture an iPhone." ASYMCO (14 April), www.asymco.com. . 2013. "Apple Retail Revenues per Visitor Reach New Record." ASYMCO (20 May), www.asymco.com.

Dedrick, Jason, Kenneth Kraemer and Greg Linden. 2009. "Who Profits from Innovation in Global Value Chains? A Study of the iPod and Notebook PCs." Industrial and Corporate Change 19(1): 81-116.

Diedrich, Philippe. 2013. "Are Manufacturing Jobs Moving Back to the U.S.?” VOXXI (13 July), www.voxxi.com.

Duhigg, Charles. 2012. “Apple’s Jobs to Obama.” New York Times (23 January).

Duhigg, Charles and David Barboza. 2012. "In China, Human Costs Are Built into an iPad." New York Times (25 January). 
Dunaway, Wilma A. 2003. "Women's Labor and Nature: The $21^{\text {st }}$ Century World-System from a Radical Ecofeminist Perspective." In New Theoretical Directions for the $21^{\text {st }}$ Century World-System, ed. W. A. Dunaway. Westport, CT: Praeger, 183-202. . 2012. "The Semiproletarian Household over the Longue Duree of the World-System." In The Longue Durée of the Modern World-System, ed. Richard Lee. Albany, NY: SUNY Press. . ed. 2014. Gendered Commodity Chains: Seeing Women's Work and Households in Global Production. Stanford: Stanford University Press.

Ecolibris. 2011. "How Green Is Your iPad?" http://www.ecolibris.net/ipad.asp.

Economix Editors. 2010. "The iEconomy: How Much Do Foxconn Workers Make?" New York Times (February 24).

Ellinor, Rebecca. 2013. “Apple Named World's Best Supply Chain.” Supply Management (24 May), www.supplymanagement.com.

Emmanuel, Argarhi. 1972. Unequal Exchange: A Study of the Imperialism of Trade. London: New Left Books.

EPT Newsletter. 2010, www.ventureoutsource.com (April).

Fair Labor Association. 2012. "Independent Investigation of Apple Supplier, Foxconn," www.fairlabor.org.

Fan, Cindy. 2004. "The State, the Migrant Labor Regime and Maiden Workers in China." Political Geography 23: 283-305.

Foster, John, and Robert McChesney. 2012. "The Global Stagnation and China." Monthly Review 63(9): 3-21.

Friends of Nature. 2011. "The Other Side of Apple," www.ipe.org.cn.

Gereffi, Gary, John Humphrey, and Timothy Sturgeon. 2005. "The Governance of Global Value Chains." Review of International Political Economy 12(1): 78-104.

Goldman, David. 2012. "Why Apple Will Never Bring Manufacturing Jobs Back to the U.S." CNN Money (17 October).

Hangen, Nathan. 2010. "7 Key Strategies that You Must Learn from Apple's Marketing." Kissmetrics (13 April), http://blog.kissmetrics.com.

Hopkins, Terence and Immanuel Wallerstein. 1986. "Commodity Chains in the World-Economy Prior to 1800." Review 10(1): 157-70.

Huang, Yasheng. 2008. Capitalism with Chinese Characteristics: Entrepreneurship and the State. London: Cambridge University Press.

ifixit. 2010. "ipad 3G Teardown." (30 April), www.ifixit.com.

International Labour Organization. 2001. "World Labour Report 2000: Income Security and Social Protection in a Changing World," www.ilo.org/publns.

Jorgensen, Andrew, and James Rice. 2012. "The Sociology of Ecologically Unequal Exchange in Comparative Perspective." In Routledge Handbook of World-Systems Analysis, eds. Salvatore Babones and Christopher Chase-Dunn. London: Routledge, 431-39.

Kalecki, M. 1954. Theory of Economic Dynamics: An Essay on Cyclical and Long-run Changes in the Capitalist Economy. London: Allen and Unwin.

Kaplinsky, Raphael and Mike Morris. 2001. A Handbook for Value Chain Research. Cape Town: University of Cape Town. 
Kraemer, Kenneth, Greg Linden, and Jason Dedrick. 2011. "Capturing Value in Global Networks: Apple's iPad and Phone." University of California Irvine, http://pcic.merage.uci.edu.

Kumar, Rakesh. 2008. Fabless Semiconductor Implementation. New York: McGraw Hill.

Lasky, Ron. 2010. “Assembled Cost of an iPad," http://blogs.indium/blog/an-interview-with-theprofessor.

Lewis, Arthur. 1954. "Economic Development with Unlimited Supplies of Labour." Manchester School 22 (May): 139-91.

Lin, Vivian. 2004. "Women Workers and Health: Semiconductor Industry in Singapore and Malaysia." In Women Workers in Industrialising Asia: Costed, Not Valued, ed. Amarjit Kaur. New York: Palgrave Macmillan, 173-94.

Linden, Greg, Jason Dedrick and Kenneth Kraemer. 2011. "Innovation and Job Creation in a Global Economy: The Case of Apple's iPod." Journal of International Commerce and Economics 3: 233-39.

Lino, Mark. 2012. "Expenditures on Children by Families, 2011." Center for Nutrition Policy and Promotion, U.S. Department of Agriculture, Miscellaneous Publication, 1528-2011.

Locke, Richard. 2013. The Promise and Limits of Private Power: Promoting Labor Standards in a Global Economy. London: Cambridge University Press.

Marx, Karl. 1858. Grundrisse: Outlines of the Critique of Political Economy. Notebook 4. Archived at www.marxists.org/archive/marx/works/1857/grundrisse/ch08.htm. . 1993. Capital. New York: Penguin Classics, 3 vols.

Mies, Maria, Veronika Bennholdt-Thomsen, and Claudia von Werlhof. 1988. Women: The Last Colony. London: Zed Books.

Miller, Jeffrey and Thomas Vollmann. 1985. "The Hidden Factory." Harvard Business Review (September): 142-50.

Moorman, Christine. 2012. "Why Apple Is a Great Marketer." Forbes (10 July).

Panek, Richard. 2011. The 4 Percent Universe: Dark Matter, Dark Energy, and the Race to Discover the Rest of Reality. New York: Houghton Mifflin.

Parnreiter. Christof. 2012. "Global Cities, Global Commodity Chains and the Geography of Core-ness in the Capitalist World-System." In Routledge Handbook of World-Systems Analysis, eds. Salvatore Babones and Christopher Chase-Dunn. London: Routledge, 231238.

Portes, Alejandro. 1983. "The Informal Sector: Definition, Controversy and Relation to National Development." Review 7(1): 151-74.

Pun, Ngai. 2007. "Gendering the Dormitory Labor System: Production, Reproduction, and Migrant Labor in South China.” Feminist Economics 13(3): 239-58

Pun, Ngai, and Lu Huilin. 2010. "Unfinished Proletarianization: Self, Anger and Class Action of the Second Generation of Peasant Workers in Reform China." Modern China 3(5): 493519.

Pun, Ngai, and Jenny Chan. 2012. "Global Capital, the State, and Chinese Workers: The Foxconn Experience.” Modern China 38(4): 383-410. 
Qi, Liangshu and Xiao-Yuan Dong. 2013. "Housework Burdens, Quality of Market Work Time, and Men's and Women's Earnings in China." University of Winnipeg, Department of Economics, Working Paper 2013-01.

Rassweiler, Andrew. 2010. "User-Interface-Focused iPad Changes the Game in Electronic Design," www.isuppli.com (April 7).

Roach, Stephen. 2004. "How Global Labor Arbitrage Will Shape the World Economy." Global Agenda Magazine, www.globalagendamagazine.com/2004/stephenroach.asp.

Robinson, Joan. 1993. The Economics of Imperfect Competition. London: Macmillan.

[SACOM] Students and Scholars against Corporate Misbehavior. 2011. "Foxconn and Apple Fail to Fulfill Promises: Predicaments of Workers after the Suicides," http://sacom.hk/archives/837.

Salary Wizard. 2013. "Electronics Assembler I.” www.salarywizard.com (July).

Satariano, Adam and Peter Burrows. 2011. "Apple's Supply-Chain Secret? Hoard Lasers." Bloomberg Businessweek (3 November).

Selden, Mark and Wu Jieh-min. 2011. "The Chinese State, Incomplete Proletarianization and Structures of Inequality in Two Epochs." Japan Focus (26 May).

Smith, Joan and Immanuel Wallerstein, eds. 1992. Creating and Transforming Households: The Constraints of the World-Economy. Cambridge: Cambridge University Press.

Smith, Joan, Immanuel Wallerstein, and Hans-Dieter Evers, eds. 1984. Households and the World-Economy. Beverly Hills, CA: Sage.

Sturgeon, Timothy and Ji-Ren Lee. 2005. "Industry Co-Evolution: A Comparison of Taiwan and North American Electronics Contracts Manufacturers." In Global Taiwan: Building Competitive Strengths in a New International Economy, eds. Suzanne Berger and Richard Lester. Armonk: M.E. Sharpe, 33-75.

Sustainable Trade Initiative. 2011. "Electronics," www.idhsustainabletrade.com/electronics.

Tabak, Faruk and Michaeline Crichlow, eds. 2000. Informalization: Process and Structure. Baltimore: Johns Hopkins University Press.

Talbot, John. 2004. Grounds for Agreement: The Political Economy of the Coffee Commodity Chain. Boulder: Rowman and Littlefield.

. 2011. "The Coffee Commodity Chain in the World-Economy: Arrighi's Systemic Cycles and Braudel's Layers of Analysis." Journal of World-Systems Research 17(1): 5888.

Thomke, Stefan and Barbara Feinberg. 2010. "Design Thinking and Innovation at Apple." Harvard Business School, Case 9-609-066.

Thompson, Nicholas. 2012. "Does Apple Have a Bruise? New Yorker (5 October).

Tu, Nan and Danju Zhang. 2010. "How Much Does it Cost to Make It? Product Costing in a Chinese Small Manufacturing Company." Paper presented to the $8^{\text {th }}$ International Conference on Supply Chain Management and Informational Systems, Hong Kong, October 6-9.

United Nations. 2003. The World's Women 2000: Trends and Statistics. New York: Oxford University Press.

Wallerstein, Immanuel. 1983. Historical Capitalism. London: Verso. 
. 1987. "Historical Systems as Complex Systems." European Journal of Operational Research 30: 203-207.

. 2004. World-systems Analysis: An Introduction. Durham: Duke University Press.

. 2009. "Crisis of the Capitalist System: Where Do We Go from Here?" MRZine (11

December), http://mrzine.monthlyreview.org/2009/wallerstein121109.html.

Wieland, Devin. 2012. "Apple's Thermonuclear War in Mobile Patent Litigations." AppChronicles (11 July).

Wikipedia. 2013. "iPad," www.wikipedia.org.

Wilcox, Joe. 2011. “Apple Patent Lawsuits Are Hypocritical.” BetaNews (24 September). . 2012. “Apple's Perception Problem Is HUGE.” BetaNews (17 December).

Wingfield, Nick. 2012. "Apple Case Muddies the Future of Innovation." New York Times (26 August).

World Bank. 2007. "Cost of Pollution in China," http://go.worldbank.org/FFCJVBTP40.

Yoffie, David and Renee Kim. 2011. "Apple in 2010." Harvard Business School, Case 9-710467.

Yu, Mi, Xu Xiao Hing and Apo Leong. 2008. "Informal Employment in China," Paper presented at Asia Pacific Research Network Conference, Cebu, Philippines (December 4).

Zeiler, David. 2012. "Why Apple Won't Ditch Controversial Foxconn." Money Morning (September 27). 


\section{Journal of World-Systems Research}

\section{Appendix}

Table 6. Dark Value from Underpaid Labor in the iPad Tier 2 Suppliers

\begin{tabular}{|c|c|c|c|c|c|}
\hline Basis & $\begin{array}{c}\text { A } \\
\$ \text { Cost per Unit }\end{array}$ & & $\begin{array}{c}\text { B } \\
\text { U.S. } \\
\text { Multiplier }\end{array}$ & $\begin{array}{c}\text { C } \\
\text { \$ Cost if produced } \\
\text { in U.S. }\end{array}$ & $\begin{array}{c}\text { D } \\
\$ \text { Dark } \\
\text { Value }\end{array}$ \\
\hline Waged Labor in Direct & China \& Philippines & 19 & 12 & 228 & 209 \\
\hline \multirow[t]{2}{*}{ Production } & Korea & 4 & 2 & 8 & 4 \\
\hline & Taiwan & 2 & 5 & 10 & 8 \\
\hline Engineers \& Management in & China \& Philippines & 12 & 8 & 96 & 84 \\
\hline \multirow[t]{2}{*}{ Production Facilities } & Korea & 5 & 3 & 15 & 10 \\
\hline & Taiwan & 3 & 4 & 12 & 9 \\
\hline Totals & & 45 & & 369 & 324 \\
\hline \multicolumn{6}{|c|}{$\begin{array}{l}\text { Sources and Notes: The direct production wage }(\$ 25) \text { is taken from Kraemer et al. (2011: 11) who estimate that only about } \$ 2 \text { of } \\
\text { this is paid to Chinese labor. On the basis of Apple }(2012) \text { and internet reports by each of the direct suppliers about factories near } \\
\text { the iPad assembly sites, I located probable production sites. I allocated } \$ 16 \text { to Chinese labor and } \$ 3 \text { to Philippine workers, the } \\
\text { location of a Toshiba factory. The difference between these estimates is largely based on distinguishing between subassembly in } \\
\text { China and component production in countries other than China in } 2010 \text {. "Many components, such as batteries and touchscreens, } \\
\text { receive their final processing in China in factories owned by foreign firms" (Kraemer et al. 2011: } 8 \text { ). I estimate the Chinese wage } \\
\text { at } \$ 2 \text { per hour ( } 2010) \text {, a generous upgrading of the } \$ 1.36 \text { reported by the Bureau of Labor Statistics for } 2008 \text { (Bannister and Cook } \\
2011 \text { ) and the cost reported for Samsung's Chinese factories, } \$ 1.30 \text { to } \$ 1.60 \text { base pay in } 2012 \text { (China Labor Watch } 2012 \mathrm{~b}) \text {. The } \\
\text { Korean wage ( } \$ 23) \text { and the Taiwanese wage }(\$ 10) \text { are from BLS }(2013) \text {; the multipliers are } 2 \text { and 5. The U.S. rate that I use is the } \\
\text { "median expected wage" for a typical Electronics Assembler II: } \$ 35,000 \text { basic wage, plus } \$ 17,000 \text { in benefits, thus } \$ 52,000 \text { year } \\
\text { (Salary Wizard 2013). I adjusted this number downward to } \$ 48,000 \text { to account for raises since } 2010 \text {, thus } \$ 24 \text { per hour, leading to } \\
\text { a multiplier of } 12 \text {. For the basis for estimating the salary costs of engineers/management, see Table } 3 \text {. The measures and } \\
\text { multipliers are derived from Linden et al. ( } 2011) \text {. Numbers are rounded. }\end{array}$} \\
\hline
\end{tabular}

Table 7. Dark Value Extracted from Underpaid Labor in Tier 3 ( Non-Core Production of Subcomponents)

\begin{tabular}{|c|c|c|c|c|}
\hline Basis & $\begin{array}{c}\text { A } \\
\$ \text { Cost per } \\
\text { Unit }\end{array}$ & $\begin{array}{c}\text { B } \\
\text { U.S. Multiplier }\end{array}$ & $\begin{array}{c}\text { C } \\
\$ \text { Cost if produced } \\
\text { in U.S. }\end{array}$ & $\begin{array}{c}\text { D } \\
\text { \$ Dark } \\
\text { Value }\end{array}$ \\
\hline $\begin{array}{l}\text { NIC Waged Labor in Direct } \\
\text { Production }\end{array}$ & 6 & $\begin{array}{l}\text { Range of } 2 \text { to } 5 \text { for } \\
\text { Korea and Taiwan }\end{array}$ & 15 & 9 \\
\hline $\begin{array}{l}\text { Chinese Waged Labor in Direct } \\
\text { Production }\end{array}$ & 6 & 12 & 72 & 66 \\
\hline $\begin{array}{l}\text { NIC Engineers \& Management in } \\
\text { Production Facilities }\end{array}$ & 7 & $\begin{array}{l}\text { Range of } 2 \text { to } 5 \text { for } \\
\text { Korea and Taiwan }\end{array}$ & 23 & 16 \\
\hline $\begin{array}{l}\text { Chinese Engineers \& Management } \\
\text { in Production Facilities }\end{array}$ & 3 & 8 & 24 & 21 \\
\hline Totals & 22 & & 134 & 112 \\
\hline \multicolumn{5}{|c|}{$\begin{array}{l}\text { Sources and Notes: NIC refers to Korea and Taiwan. In order to estimate the dark value contribution from these tiers, it is } \\
\text { necessary to continue the process of "teardown" or reverse engineering. I traced the likely main suppliers of Tier } 2 \text { by home and } \\
\text { production locations. Much of the production in this tier is by subsidiaries. The supply chains of Korean firms are largely in } \\
\text { Korea. Other firms that have subassembly plants in China tend to have immediate suppliers there. In Part A, the estimated costs } \\
\text { of materials for Tier } 2 \text { suppliers ( } \$ 154) \text { is the received sales price for the Tier } 3 \text { sub-component suppliers. This } \$ 154 \text { must be } \\
\text { allocated in four ways: for previously obtained materials, direct labor, gross margin (overhead and profit), and value added taxes, } \\
17 \% \text {, if collected, in China. After deducting the tax cost, the other costs were distributed in accordance with patterns found in } \\
\text { Tier } 2 \text {. The basis for the estimation of wage and salary rate and multipliers is found in Table } 6 \text { notes. Indirect costs have been } \\
\text { estimated in the manner previously indicated. The multiplier for cheap labor zones direct production wages and NIC } \\
\text { compensation costs from overhead are carried over from Table } 6 \text {. The multiplier for cheap labor zones compensation costs from } \\
\text { overhead is derived from the Linden et al.'s }(2011: 229) \text { estimate of engineers' average salaries in the U.S. and China. }\end{array}$} \\
\hline
\end{tabular}

